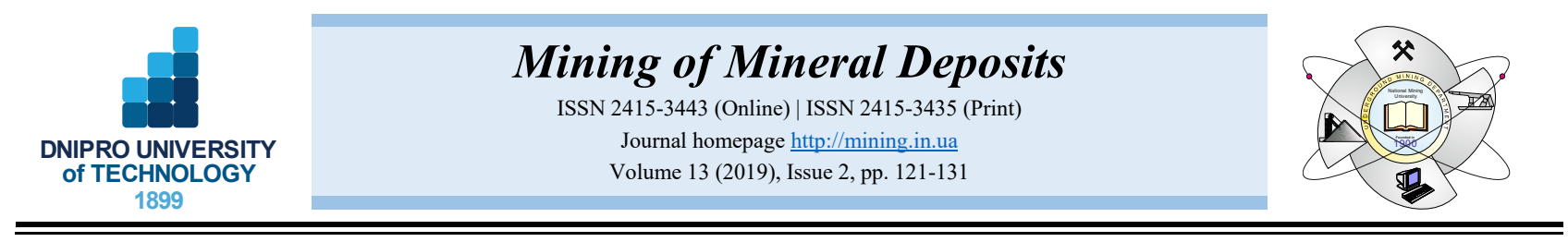

UDC 622.831

https://doi.org/10.33271/mining13.02.121

\title{
NUMERICAL MODELLING OF THE EFFECT OF TEMPERATURE VARIATION ON STOPE STABILITY IN BUSHVELD IGNEOUS COMPLEX
}

\author{
G.O. Oniyide ${ }^{1,2^{*}}$, M.A. Idris ${ }^{2,3}$ \\ ${ }^{1}$ University of the Witwatersrand, Johannesburg, South Africa \\ ${ }^{2}$ Federal University of Technology Akure, Akure, Nigeria \\ ${ }^{3}$ Luleå University of Technology, Luleå, Sweden \\ *Corresponding author: e-mail engroniyide@gmail.com, tel. +2348102043388
}

\begin{abstract}
Purpose. This paper presents the result of the research carried out on the effect of increasing temperature and stresses with depth of mining on the stability of stope within the Bushveld Igneous Complex (BIC), where the South African Platinum mines are located.

Methods. The stability of stope at the platinum mine was analysed using numerical modelling. A commercial geotechnical software, FLAC (Fast Lagrangian Analysis of Continua), was used for the numerical modelling to study and to understand the behaviour of the rock in the deep and hot underground excavations. The modelling is hypothetical in the sense that there are no direct field measurements of failure or displacements. However, some field data received from the mines include virgin rock temperature, in-situ stress data.

Findings. The plots of the yielded zones of the model for excavations at the depths of 1073, 2835 and $5038 \mathrm{~m}$ revealed that there would be shear and tensile failures at 2835 and $5038 \mathrm{~m}$, however, these failures will be higher at $5038 \mathrm{~m}$ than what will be witnessed at shallow depths. This observation could be attributed to higher in-situ stresses and virgin rock temperatures.

Originality. Major researches on the platinum mine have not extensively consider the influence of the increased temperature at the ultra-depth level hence this study aims to fill the gap by studying the effect of the increased temperature and stresses on the stability of stopes at the ultra-depth levels within the BIC.

Practical implications. This research showed that mining at ultra-deep levels would pose a challenge of an increase in horizontal and vertical displacements with increasing depth. It is recommended that horseshoe-shaped stopes could be preferred in such conditions to avoid high-stress concentration at the corners of the roof of the stopes, which may reduce failures from shallow-depth to ultra-depth levels. Also, based on the magnitude of convergence that will be experienced at ultra-deep mining levels (3500 to $5000 \mathrm{~m}$ ), it is recommended that access development is located in the more competent strata, such as in mottled anorthosite with an average UCS of $82 \mathrm{MPa}$.
\end{abstract}

Keywords: temperature variation, numerical modelling, laboratory testing, Bushveld rocks, platinum mines

\section{INTRODUCTION}

The platinum mines are in the Bushveld Igneous Complex (BIC), which is located in the northern part of South Africa. The BIC is the world's largest layered intrusion. It is about seven to nine kilometers thick and is divided into eastern, western and northern limbs. Its upper critical zone hosts the world's largest deposit of platinum group elements (PGE), (Schouwstra, Kinloch, \& Lee, 2000).

There are some numerical modelling analyses on the influence of temperature on the behaviour of rocks carried out by previous researchers. Kim \& Yang
(2001) studied the behaviour of rock surrounding an underground storage cavern using thermal properties of the rock. The distribution of heat and the thermal stress in the cavern were modelled using a numerical code FLAC (Fast Lagrangian Analysis of Continua). They reported that only the dead weight of the overburden contribute towards the major stress before the storage of low-temperature material (refrigerated foods). However, after the storage, the maximum principal stress at the sidewall of the cavern increased more than $60 \%$ because of the thermal stress.

The major areas where research have focused on, in relation to depth in the platinum mines, are the influence

(C) 2019. G.O. Oniyide, M.A. Idris. Published by the Dnipro University of Technology on behalf of Mining of Mineral Deposits.

This is an Open Access article distributed under the terms of the Creative Commons Attribution License (http://creativecommons.org/licenses/by/4.0/),

which permits unrestricted reuse, distribution, and reproduction in any medium, provided the original work is properly cited. 
of an increase in the rock stresses, development of new mining methods with improved mechanization, pillar design, ventilation, and impact of temperature on the mine workers, in case of inadequate ventilation. For example, Biffi, Stanton, Rose, \& Pienaar (2007) outlined some of the ventilation challenges associated with deeper platinum mining and gave an overview of the strategies that could be employed in tackling them. The effect of the temperate variation on the stability of the stope at a depth within the Bushveld rock mass complex has not been adequately investigated and reported in the literature hence the need for this study.

\section{GEOLOGY OF THE BUSHVELD COMPLEX}

Based on lithostratigraphic classification (Ryder \& Jager, 2002), BIC is divided into Lebowa Granite Suite, Rashoop Granophyre Suite and Rustenburg Layered Suite (RLS). The RLS is described as the main body of the Bushveld Complex. It comprises $7000 \mathrm{~m}$ (West) to $9000 \mathrm{~m}$ (East) of basic igneous rock types, which intrude into the formation of Transvaal sequence. Its thickness is $9 \mathrm{~km}$. Aside from the fine-grained basal norite, there is an upward change from ultra-basic rocks towards the base to basic rocks higher in the RLS succession. The RLS is further divided into upper, main, critical and lower zones. The critical zone is where the most important mining activities take place because of its richness in Platinum Group Elements (Fig. 1).

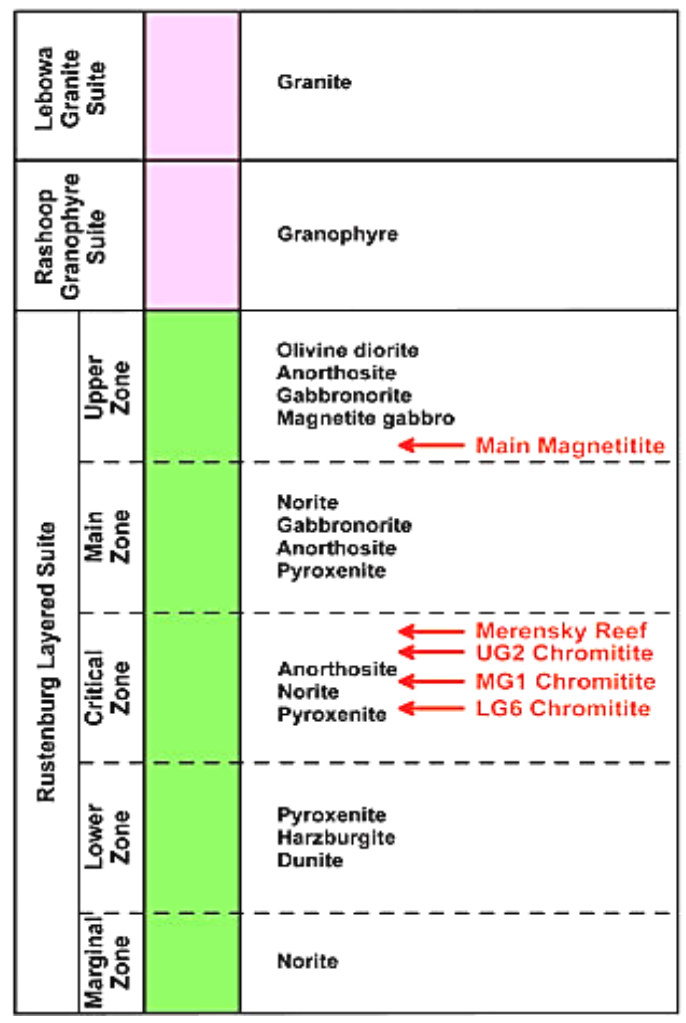

Figure 1. Generalized stratigraphic column for the Bushveld Complex indicating predominant rock types (Jones, 2015)

The primary host rock types in the South African Platinum mines are Norite (N), Leuconorite (LN), Mottled anorthosite (MA), Pyroxenite (PX) and Chromitite (CR).

\section{NUMERICAL MODELLING}

This paper examines the influence of temperature on the behaviour of the Bushveld rock mass around the underground excavation using numerical modelling. The numerical code used for the analyses is FLAC 2D (Itasca Consulting Group, 2012). The FLAC thermal conduction model was coupled with the mechanical model for the thermo-mechanical analyses.

The conduction model allows simulation of transient heat conduction in materials and the development of thermally induced displacement and stresses. In the following sections, the virgin rock temperature (VRT) of the in situ stresses, the rock mass properties, and model geometry used for the numerical modelling are briefly discussed.

\subsection{Virgin rock temperature (VRT)}

The virgin rock temperature data for the BIC, as shown in Figure 2 was sourced from the Corporate Office of Anglo American Platinum Limited, Mine Ventilation and Refrigeration Engineering Unit.

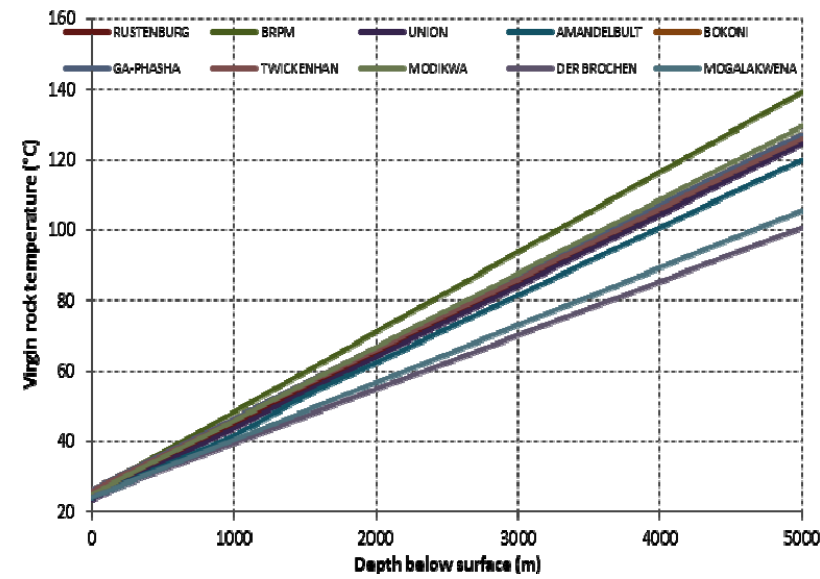

Figure 2. Graph of virgin rock temperature against depth for platinum mines

Figure 2 shows that Der Brochen mine has the lowest temperature gradient, while Bafokeng-Rasimoni Platinum Mine (BRPM) has the highest.

For the numerical modelling, the VRT of BRPM was used since it has the highest thermal gradient so that the influence of temperature would also be the highest. Simpson (2011) advised that it is essential that engineering designers carefully consider the worst situation and parameter values that could be imagined based on a reasonable and well- informed engineering assessment. Using the information in Figure 2, the VRT equation for $\mathrm{BRPM}$ is given as:

$y=0.0227 x+25.64$;

and

$x=\frac{y-25.64}{0.0227}$,

where:

$y$ - the VRT;

$x$ - the depth below the surface, in meters. 
Table 1 shows the equivalent depths for the temperatures $\left(50,70,90,110\right.$ and $\left.140^{\circ} \mathrm{C}\right)$ on which the laboratory testing was based. The temperature-depth relationship (1) was used in the numerical modelling.

Table 1. Temperatures and equivalent depths for BRPM

\begin{tabular}{cc}
\hline Temperature, ${ }^{\circ} \mathrm{C}$ & Depth, $\mathrm{m}$ \\
\hline 50 & 1073 \\
70 & 1954 \\
90 & 2835 \\
110 & 3716 \\
140 & 5037 \\
\hline
\end{tabular}

\subsection{In-situ rock stresses}

The in-situ stress measurement data was obtained through correspondence with the Principal Rock Engineer at Anglo American Platinum Limited. The method used for the stress measurement is overcoring technique. The primary data reported from the overcoring stress measurements are:
- the Magnitude and orientation (bearing and dip) of three principal stresses;

- the vertical, maximum and minimum horizontal stresses.

The average densities $\left(\mathrm{kg} / \mathrm{m}^{3}\right)$ of some of the rocks from the Bushveld Igneous Complex is given in Table 2.

\section{Table 2. Densities of rocks from the platinum mines}

\begin{tabular}{lccccc}
\hline Types of rock & CR & LN & MA & N & PX \\
\hline Density $\left(\mathrm{kg} / \mathrm{m}^{3}\right)$ & 4049 & 2776 & 2744 & 3045 & 3194 \\
\hline
\end{tabular}

The average of all rock densities is $3061 \mathrm{~kg} / \mathrm{m}^{3}$. The average value was used in the calculation of the vertical stress for the numerical modelling.

The summary of the principal stress magnitudes is provided in Table 3 where $\sigma_{v}$ is the vertical stress, while $\sigma_{h 1}$ and $\sigma_{h 2}$ are the major and minor horizontal principal stresses, respectively. The maximum and minimum horizontal-to-vertical stress ratio are $k_{1}$ and $k_{2}$, respectively.

Table 3. Principal stresses from platinum mines

\begin{tabular}{|c|c|c|c|c|c|c|c|c|c|c|}
\hline $\mathrm{S} / \mathrm{N}$ & Mines & $\sigma_{1}, \mathrm{MPa}$ & $\sigma_{2}, \mathrm{MPa}$ & $\sigma_{3}, \mathrm{MPa}$ & $\sigma_{v}, \mathrm{MPa}$ & $\sigma_{h 1}, \mathrm{MPa}$ & $\sigma_{h 2}, \mathrm{MPa}$ & $k_{1}$ & $k_{2}$ & Depth, m \\
\hline 1 & Lebowa & $\begin{array}{c}16 \\
\left(11^{\circ} / 33^{\circ}\right)\end{array}$ & $\begin{array}{c}9 \\
\left(263^{\circ} / 26^{\circ}\right)\end{array}$ & $\begin{array}{c}4 \\
\left(144^{\circ} / 46^{\circ}\right)\end{array}$ & 8.5 & 11.9 & 8.1 & 1.4 & 1.0 & 297 \\
\hline 2 & Lebowa & $\begin{array}{c}30 \\
\left(128^{\circ} / 1^{\circ}\right)\end{array}$ & $\begin{array}{c}21 \\
\left(218^{\circ} / 13^{\circ}\right)\end{array}$ & $\begin{array}{c}10 \\
\left(35^{\circ} / 77^{\circ}\right)\end{array}$ & 10 & 26 & 24 & 2.4 & 2.6 & 472 \\
\hline 3 & Lebowa & $\begin{array}{c}36 \\
\left(76^{\circ} / 13^{\circ}\right)\end{array}$ & $\begin{array}{c}25 \\
\left(329^{\circ} / 52^{\circ}\right)\end{array}$ & $\begin{array}{c}16 \\
\left(175^{\circ} / 35^{\circ}\right)\end{array}$ & 22 & 35 & 19 & 0.9 & 1.6 & 470 \\
\hline 4 & Rustenburg & $\begin{array}{c}55.1 \\
\left(227^{\circ} / 29^{\circ}\right)\end{array}$ & $\begin{array}{c}32.7 \\
\left(124^{\circ} / 21^{\circ}\right)\end{array}$ & $\begin{array}{c}26.1 \\
\left(3^{\circ} / 53^{\circ}\right)\end{array}$ & 33.6 & 41.9 & 38.4 & 1.1 & 1.2 & 1097 \\
\hline 5 & Rustenburg & $\begin{array}{c}47.1 \\
\left(224^{\circ} / 17^{\circ}\right)\end{array}$ & $\begin{array}{c}28.5 \\
\left(128^{\circ} / 19^{\circ}\right)\end{array}$ & $\begin{array}{c}19.9 \\
\left(351^{\circ} / 64^{\circ}\right)\end{array}$ & 23.1 & 36.7 & 35.8 & 1.5 & 1.6 & 1097 \\
\hline 6 & Rustenburg & $\begin{array}{c}40.3 \\
\left(119^{\circ} / 45^{\circ}\right)\end{array}$ & $\begin{array}{c}31.5 \\
\left(318^{\circ} / 44^{\circ}\right)\end{array}$ & $\begin{array}{c}25.8 \\
\left(219^{\circ} / 9^{\circ}\right)\end{array}$ & 35.8 & 32.7 & 29.2 & 0.8 & 0.9 & 1204 \\
\hline 7 & Rustenburg & $\begin{array}{c}63 \\
\left(-9^{\circ} / 20^{\circ}\right)\end{array}$ & $\begin{array}{c}26 \\
\left(-174^{\circ} / 20^{\circ}\right)\end{array}$ & $\begin{array}{c}15 \\
\left(83^{\circ} / 5^{\circ}\right)\end{array}$ & 30 & 58 & 16 & 1.9 & 0.5 & 1080 \\
\hline 8 & Rustenburg & $\begin{array}{c}44 \\
\left(85^{\circ} / 34^{\circ}\right)\end{array}$ & $\begin{array}{c}32 \\
\left(-67^{\circ} / 53^{\circ}\right)\end{array}$ & $\begin{array}{c}23 \\
\left(-176^{\circ} / 14^{\circ}\right)\end{array}$ & 35 & 40 & 24 & 0.7 & 1.1 & 1130 \\
\hline
\end{tabular}

\subsubsection{Stress magnitudes used for modelling}

Handley (2013) suggested a generic pre-mining linear stress model (i.e. (3), (4) and (5)) for southern Africa to calculate the vertical, maximum and minimum horizontal stresses at a mining depth $(h)$ :

$$
\begin{aligned}
& \sigma_{v}=81+0.027(h-3000) ; \\
& \sigma_{h_{1}}=87+0.026(h-3000) ; \\
& \sigma_{h_{2}}=48+0.015(h-3000) .
\end{aligned}
$$

The model was derived from plots of 180 consistent in-situ stress measurements through a combination of the gradient and intercept of the graph (Fig. 3).

Handley (2013) used a density of $2700 \mathrm{~kg} / \mathrm{m}^{3}$ in (3), (4) and (5), which was derived from the Southern African stress measurement database. The average rock density in the platinum mines, however, is approximately $3061 \mathrm{~kg} / \mathrm{m}^{3}$. Therefore, (3), (4) and (5) were modified by replacing the gradient of the vertical stress, 0.027 with 0.03061 .

The ratio $0.03061 / 0.027$, that is, 1.134 was used to adjust the intercept and gradient for the major and minor horizontal stress in the equations.

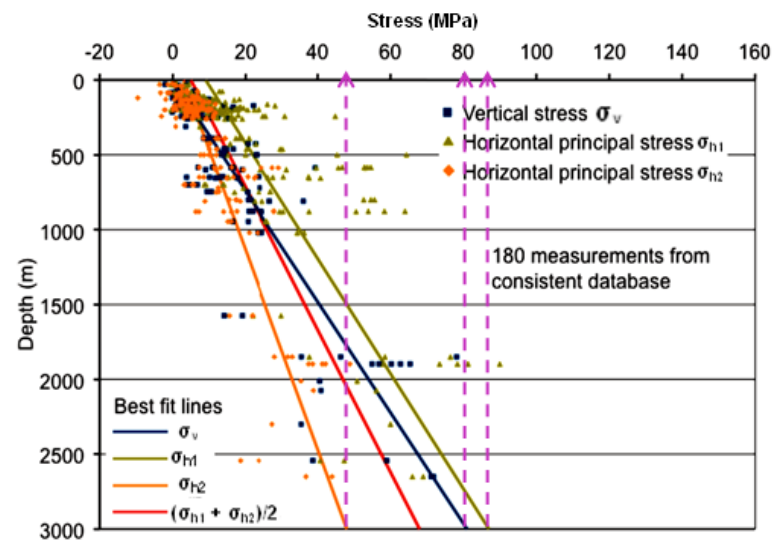

Figure 3. Plot of consistent stress measurement database (Handley, 2013)

The modified equations, for the calculation of the stresses (Table 4) for the numerical modelling are given in (6), (7) and (8) as:

$$
\begin{aligned}
& \sigma_{v}=91.8+0.0306(h-3000) ; \\
& \sigma_{h_{1}}=98.1+0.0297(h-3000) ; \\
& \sigma_{h_{2}}=54+0.017(h-3000) .
\end{aligned}
$$


Table 4. Vertical and horizontal stresses used for numerical modelling

\begin{tabular}{cccccc}
\hline $\mathrm{S} / \mathrm{N}$ & Temperature, ${ }^{\circ} \mathrm{C}$ & Depth, $\mathrm{m}$ & $\begin{array}{c}\sigma_{v}, \\
\mathrm{MPa}\end{array}$ & $\begin{array}{c}\sigma_{h 1}, \\
\mathrm{MPa}\end{array}$ & $\begin{array}{c}\sigma_{h 2}, \\
\mathrm{MPa}\end{array}$ \\
\hline 1 & 50 & 1073.1 & 32.8 & 40.9 & 21.2 \\
2 & 90 & 2835.2 & 86.8 & 93.2 & 51.2 \\
3 & 140 & 5037.9 & 154.2 & 158.6 & 88.6 \\
\hline
\end{tabular}

\subsection{Determination of rock mass}

\section{properties for numerical modelling}

The rock mass properties were determined with the use of a rocscience software, RockLab. RocLab implements generalized Hoek-Brown failure criterion (Hoek, Carranza-Torres, \& Corkum, 2002) to obtain reliable estimates of the rock mass properties. The values of intact uniaxial compressive strength $\left(\sigma_{c i}\right)$, geological strength index $(G S I)$, Hoek-Brown material constant $\left(m_{i}\right)$, disturbance factor $(D)$ and intact Young's modulus $\left(E_{i}\right)$ were used as inputs in the RocLab to generate the rock mass properties needed for the numerical modelling. The rock mass properties are the deformation modulus $\left(E_{r m}\right)$, tensile strength $\left(\sigma_{t}\right)$, cohesion $(c)$, and friction angle $(\phi)$.

$G S I$ is one of the important input parameters for the Hoek-Brown failure criterion and its value can be determined on the field based on the geological description of the rock mass. The GSI values can also be estimated from RMR (Bieniawski, 1976; Bieniawski, 1989) or $Q$ index (Barton, Lien, \& Lunde, 1974). Malan \& Napier (2011) suggested the use of an RMR value of 94 and 95 for UG2 and Merensky reef, respectively at Lonmin's BIC mine. Using the relation, GSI $=\mathrm{RMR}-5$ (Hoek, Kaiser, \& Bawden, 1995), the GSI values for UG2 and Merensky reef are 89 and 90 , respectively. Watson (2010) stated that the Barton- $Q$ index values for rock mass at Amandelbult (shallow depth, $k$-ratio $=1$ ), Impala (intermediate depth, $k$-ratio $=1.3$ ), and Union (intermediate depth, $k$-ratio $=0.5)$ mines are 18.3, 50.0 and 3.2, respectively. Using the relation, $G S I=9 \ln Q+44$ (Hoek, Kaiser, \& Bawden, 1995), the GSI values for the respective mines were estimated to be 70.2, 79 and 53. Based on the GSI values reported by Malan \& Napier (2011) and Watson (2010) from the different mines, an average value of 80 was used for BIC.

The disturbance factor $(D)$ was considered to be 0.3 . Hoek, Carranza-Torres, \& Corkum (2002) drew up a set of guidelines for estimating the factor $D$. When $D=0$, it means excellent quality controlled blasting, excavation by tunnel boring machine or mechanical/hand excavation in poor quality rock with minimal disturbance to the surrounding rock. The $D$ value of 0.5 represents a situation where squeezing problems result in significant floor heave, while $D$ value of 0.8 is for very poor quality blasting in hard rock tunnel which causes severe local damage. The excavations at platinum mines are assumed to have $D$ value, which falls between 0 and 0.5 . A value of 0.3 was adopted for this modelling based on the above discussions and a report from Sellers (2011) suggesting cautious blasting such as presplitting and smooth blasting. Also, Malan \& Basson (1998) opined that squeezing would be witnessed at some depths depending on the uniaxial compressive strength of the footwall and hangingwall. Table 5 summarises the values of $\sigma_{c i}, m_{i}$, and $E_{i}$ obtained from laboratory testing of rock specimens, while Table 6 presents the rock mass cohesion, friction angle, deformation modulus and tensile strength as determined from the RockLab.

The shear modulus $(G)$ and bulk modulus $(K)$ calculated from the rock mass deformation modulus and Poisson's ratio are presented in Table 7. Also included in the table is the rock mass dilation angle $(\psi)$ that was calculated by dividing the rock mass friction angle by 4 as suggested by Hoek \& Brown (1997) for very good quality rocks.

Table 5. Intact $\sigma_{c i}$, mi and Young's modulus

\begin{tabular}{|c|c|c|c|c|c|c|c|c|c|c|c|c|c|c|c|}
\hline \multirow[b]{2}{*}{$\begin{array}{c}\text { Temp., } \\
{ }^{\circ} \mathrm{C}\end{array}$} & \multicolumn{3}{|c|}{ MA } & \multicolumn{3}{|c|}{ CR } & \multicolumn{3}{|c|}{$\mathrm{N}$} & \multicolumn{3}{|c|}{ PX } & \multicolumn{3}{|c|}{ LN } \\
\hline & $\begin{array}{c}\sigma_{c i}, \\
\mathrm{MPa}\end{array}$ & $m_{i}$ & $\begin{array}{c}E_{i}, \\
\mathrm{GPa}\end{array}$ & $\begin{array}{c}\sigma_{c i}, \\
\mathrm{MPa}\end{array}$ & $m_{i}$ & $\begin{array}{c}E_{i}, \\
\mathrm{GPa}\end{array}$ & $\begin{array}{c}\sigma_{c i}, \\
\mathrm{MPa}\end{array}$ & $m_{i}$ & $\begin{array}{c}E_{i}, \\
\mathrm{GPa}\end{array}$ & $\begin{array}{c}\sigma_{c i}, \\
\mathrm{MPa}\end{array}$ & $m_{i}$ & $\begin{array}{c}E_{i}, \\
\mathrm{GPa}\end{array}$ & $\begin{array}{c}\sigma_{c i}, \\
\mathrm{MPa}\end{array}$ & $m_{i}$ & $\begin{array}{c}E_{i}, \\
\mathrm{GPa}\end{array}$ \\
\hline 50 & 193 & 10.6 & 84 & 75 & 8.3 & 56 & 161 & 7.4 & 78 & 165 & 6.4 & 119 & 168 & 7.4 & 77 \\
\hline 90 & 185 & 10.5 & 82 & 73 & 7.6 & 54 & 160 & 7.1 & 74 & 164 & 5.9 & 115 & 163 & 7.4 & 74 \\
\hline 140 & 180 & 10.4 & 80 & 71 & 7.4 & 52 & 159 & 6.8 & 71 & 163 & 4.5 & 113 & 159 & 6.8 & 71 \\
\hline
\end{tabular}

Table 6. Rock mass cohesion, friction a deformation modulus and tensile strength as determined from RockLab

\begin{tabular}{|c|c|c|c|c|c|c|c|c|c|c|c|c|c|c|c|c|c|c|c|c|}
\hline \multirow[b]{2}{*}{$\begin{array}{c}\text { Depth, } \\
\text { m }\end{array}$} & \multicolumn{4}{|c|}{ MA } & \multicolumn{4}{|c|}{$\mathrm{CR}$} & \multicolumn{4}{|c|}{$\mathrm{N}$} & \multicolumn{4}{|c|}{ PX } & \multicolumn{4}{|c|}{ LN } \\
\hline & $\begin{array}{c}c, \\
\mathrm{MPa}\end{array}$ & $\begin{array}{r}\phi, \\
\text { deg }\end{array}$ & $\begin{array}{c}E_{r m}, \\
\mathrm{GPa}\end{array}$ & $\begin{array}{c}\sigma_{t}, \\
\mathrm{MPa}\end{array}$ & $\begin{array}{c}c \\
\mathrm{MPa}\end{array}$ & $\begin{array}{r}\phi, \\
\text { deg }\end{array}$ & $\begin{array}{c}E_{r m}, \\
\mathrm{GPa}\end{array}$ & $\begin{array}{c}\sigma_{t}, \\
\mathrm{MPa}\end{array}$ & $\begin{array}{c}c, \\
\mathrm{MPa}\end{array}$ & $\begin{array}{c}\phi, \\
\text { deg }\end{array}$ & $\begin{array}{c}E_{r m}, \\
\mathrm{GPa}\end{array}$ & $\begin{array}{c}\sigma_{t} \\
\mathrm{MPa}\end{array}$ & $\begin{array}{c}c, \\
\mathrm{MPa}\end{array}$ & $\begin{array}{r}\phi, \\
\text { deg }\end{array}$ & $\begin{array}{c}E_{r m}, \\
\mathrm{GPa}\end{array}$ & $\begin{array}{c}\sigma_{t} \\
\mathrm{MPa}\end{array}$ & $\begin{array}{c}c, \\
\mathrm{MPa}\end{array}$ & $\begin{array}{c}\phi, \\
\text { deg }\end{array}$ & $\begin{array}{l}E_{r m}, \\
\mathrm{GPa}\end{array}$ & $\begin{array}{c}\sigma_{t}, \\
\mathrm{MPa}\end{array}$ \\
\hline 1073 & 10.7 & 46.9 & 59 & 3.6 & 6.5 & 35.8 & 40 & 1.8 & 9.9 & 42.1 & 55 & 4. & 10.4 & 40.4 & 83 & 5.0 & 10.0 & 42.9 & 54 & 4.4 \\
\hline 2835 & 14.2 & 40.4 & 58 & 3.5 & 9.9 & 27.7 & 38 & 1. & 13.3 & 35.0 & 52 & 4. & 13.6 & 30. & 81 & 5.5 & 13.0 & 36.1 & 52 & 4.3 \\
\hline 5038 & 18.1 & 35.8 & 56 & 3.4 & 13.2 & 23.3 & 36 & 1.9 & 16.7 & 30.3 & 50 & 4.6 & 16.5 & 26.7 & 79 & 7.1 & 16.1 & 31.0 & 50 & 4.6 \\
\hline
\end{tabular}

Table 7. Rock mass shear (G) and bulk (K) modulus and dilation angle ( $\psi)$

\begin{tabular}{|c|c|c|c|c|c|c|c|c|c|c|c|c|c|c|c|}
\hline \multirow[b]{2}{*}{$\begin{array}{c}\text { Depth, } \\
\text { m }\end{array}$} & \multicolumn{3}{|c|}{ MA } & \multicolumn{3}{|c|}{ CR } & \multicolumn{3}{|c|}{$\mathrm{N}$} & \multicolumn{3}{|c|}{$\mathrm{PX}$} & \multicolumn{3}{|c|}{ LN } \\
\hline & $\begin{array}{c}G, \\
\mathrm{GPa} \\
\end{array}$ & $\begin{array}{c}K, \\
\mathrm{GPa} \\
\end{array}$ & $\begin{array}{c}\psi \\
\text { deg }\end{array}$ & $\begin{array}{c}G, \\
\mathrm{GPa} \\
\end{array}$ & $\begin{array}{c}K, \\
\mathrm{GPa}\end{array}$ & $\begin{array}{c}\psi, \\
\text { deg }\end{array}$ & $\begin{array}{c}G, \\
\mathrm{GPa} \\
\end{array}$ & $\begin{array}{c}K, \\
\mathrm{GPa} \\
\end{array}$ & $\begin{array}{c}\psi, \\
\text { deg }\end{array}$ & $\begin{array}{c}G, \\
\mathrm{GPa} \\
\end{array}$ & $\begin{array}{c}K, \\
\mathrm{GPa}\end{array}$ & $\begin{array}{c}\psi, \\
\text { deg }\end{array}$ & $\begin{array}{c}G, \\
\mathrm{GPa} \\
\end{array}$ & $\begin{array}{c}K, \\
\mathrm{GPa} \\
\end{array}$ & $\begin{array}{c}\psi \\
\text { deg }\end{array}$ \\
\hline 1073 & 21.9 & 71.7 & 11.9 & 13.9 & 87.8 & 9.0 & 20.7 & 51.5 & 10.5 & 33.6 & 53.9 & 10.1 & 20.1 & 57.0 & 10.7 \\
\hline 2835 & 21.4 & 71.3 & 10.1 & 13.3 & 82.8 & 6.9 & 19.4 & 55.9 & 8.7 & 32.5 & 52.2 & 7.5 & 19.4 & 52.3 & 9.0 \\
\hline 5038 & 20.6 & 67.6 & 8.9 & 12.7 & 93.6 & 5.8 & 18.7 & 49.8 & 7.6 & 31.9 & 51.6 & 6.7 & 18.7 & 47.8 & 7.8 \\
\hline
\end{tabular}




\subsection{Model set up}

\subsubsection{Model geometry}

The numerical modelling analysis was carried out using the two-dimensional FLAC version 7.00. Typical rectangular stope geometry of $10 \mathrm{~m}$ width and $1 \mathrm{~m}$ vertical height was selected for the numerical model. Egerton (2004) has reported that the average thickness of UG2 reef is 70 to $75 \mathrm{~cm}$, which is typically mined at stoping width of $1 \mathrm{~m}$ to avoid grade dilution. Egerton (2004) made a comparison between different mining methods that can be employed in the extraction of UG2 reef. Of the various methods stated, he reported a range of panel length of 8 to $30 \mathrm{~m}$ and concluded that a panel length of $10 \mathrm{~m}$ gave the best extraction rate.

For the numerical modelling, a FLAC model was chosen to be $200 \mathrm{~m}$ wide and $61 \mathrm{~m}$ high. These dimensions are large enough to avoid the boundary effect, which could affect stress distribution in the model. Roller boundary conditions were used on the vertical, top and bottom boundaries of the model.

\subsubsection{Modelling sequence}

The physical, mechanical and thermal properties were assigned accordingly for the rock types as shown in Figure 4 . The temperatures corresponding to different depths were given as initial condition.

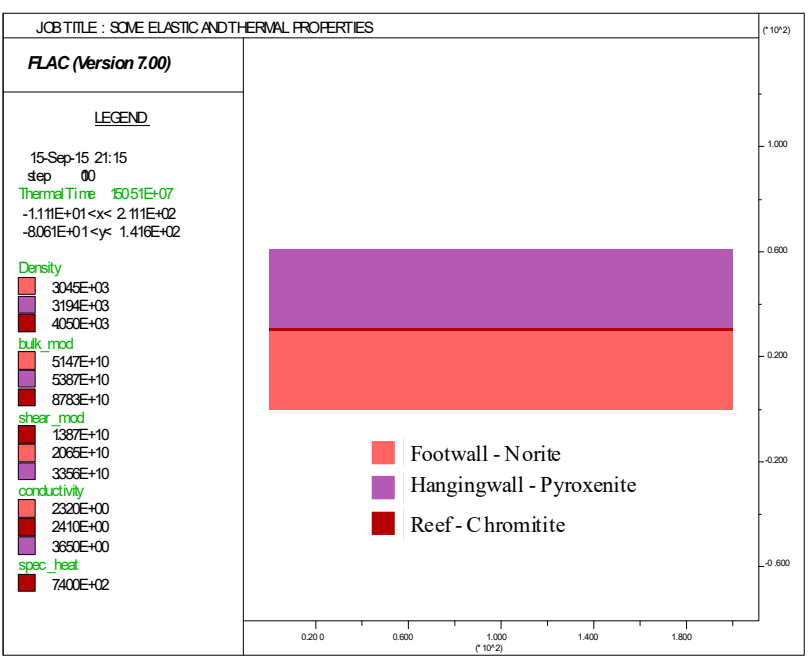

Figure 4. Some of the model properties for excavation at a depth of $1073 \mathrm{~m}$

In-situ stresses were then applied to the model. For the three depths modelled, the major horizontal stress $\left(S_{x x}\right)$, vertical stress $\left(S_{y y}\right)$ and the minor horizontal stress $\left(S_{z z}\right)$ are the major, intermediate and minor principal stresses respectively. The detail of the in-situ stresses is given in Table 4.

The acceleration due to gravity is set to be $9.81 \mathrm{~m} / \mathrm{s}^{2}$, while the model was executed in large strain mode. The model was first cycled until the desired temperature was reached, and in the meantime, the mechanical calculation is turned off to allow for only thermal cycling. After that, the mechanical is turned on, and the thermal option is turned off, to enable the mechanical calculation to be effective. The stress gradient option in FLAC was used to reproduce the effect of increasing stress with depth.
The applied in situ stresses were made to vary linearly over the entire model in order to represent the true picture of stress distribution in the rockmass.

\section{RESULTS AND DISCUSSION}

\subsection{Numerical model results}

The stability of the stope was analyzed using the plots of the yielded zone, roof and wall convergences and the failure depth.

\subsection{Yielded zones plots}

The plot displays the zones in which the stresses satisfy the Mohr-Coulomb yield criterion that is indicative of areas where a plastic flow is occurring. It should be noted that initial plastic flow often occurs at the beginning of a simulation; however, subsequent stress redistribution unloads the yielding elements so that the stresses do not satisfy the yield criterion. In the state plots, these non-yielding parts are referred to as "yield in past". The parts that satisfy the yield criterion indicate tensile or shear failure (Itasca Consulting Group, 2012).

The state plots of the model for excavations at 1073 , 2835 and $5038 \mathrm{~m}$ below the surface are given in Figures $5-7$, while Figure 8 shows the post-excavation temperature plot. The state plot for $1073 \mathrm{~m}$ (Figure 5) shows no presence of shear and tensile failures, which implies that the hangingwall and footwall are competent enough to bear the surrounding stresses.

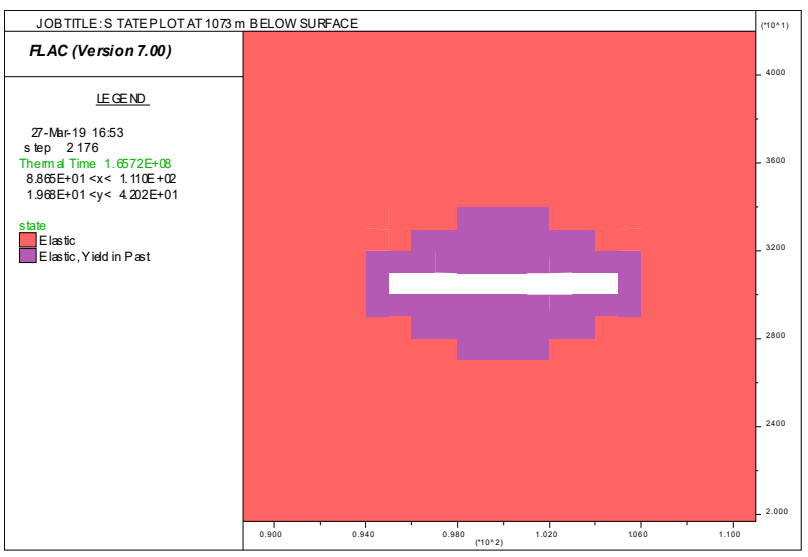

Figure 5. State plot at 1073 m below the surface

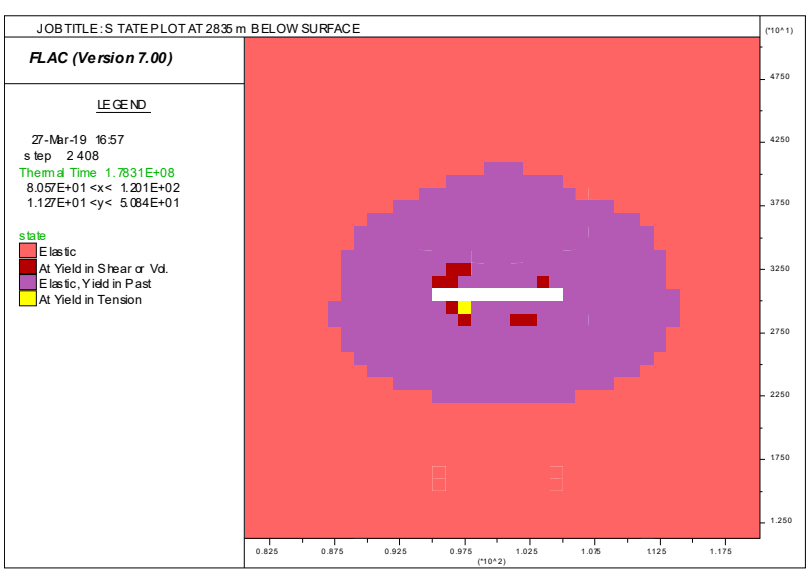

Figure 6. State plot at 2835 m below surface 


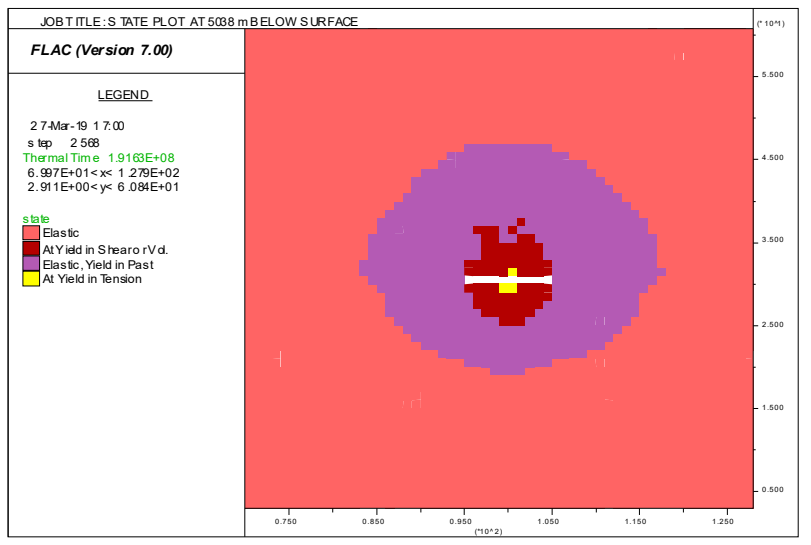

Figure 7. State plot at $5038 \mathrm{~m}$ below the surface

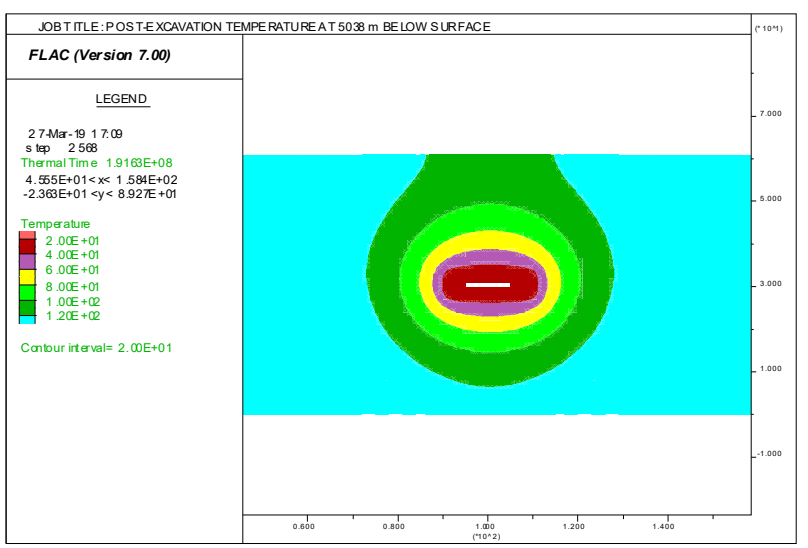

Figure 8. Post-excavation temperature at $5038 \mathrm{~m}$ below the surface

However, both shear and tensile failures are witnessed at 2835 and $5038 \mathrm{~m}$. Figures 6 and 7 reveal that these failures are greater at $5038 \mathrm{~m}$ than $2835 \mathrm{~m}$ below surface. This could be attributed to higher in-situ stresses and virgin rock temperatures. As expected, horizontal and vertical displacements are also increasing, as will be shown later with displacement plots.

Besides, one of the reasons for the increase in the tensile failure at this depth could be the rapid cooling of the excavation wall from $140^{\circ} \mathrm{C}$ to approximately $40^{\circ} \mathrm{C}$ (Fig. 8). The combined effect of high-temperature variation and mining induced stresses result in the development of micro-cracks, which coalesce to form tensile failure. Castro, Bewick, \& Carter (2012) stated that at great depth, common failure types are stress-induced failures in the form of spalling and slabbing, in addition to structurally controlled gravity-driven failures. These failures are attributed to the reduction of radial stresses and increasing tangential stresses.

\subsection{Horizontal and vertical displacements}

The aim of including the horizontal and vertical displacement plots is to examine the deformations that insitu stresses and temperature would cause at ultra-deep levels in the platinum mines. Malan and Basson (1998) noticed a severe case of squeezing at Hartebeestfontein Gold Mine. Squeezing, as defined in Malan and Basson (1998) is the time-dependent large deformation, which occurs around the excavation, and is mostly associated with creep caused by exceeding of limiting shear stress.
Malan and Basson (1998) presented a graph, which shows a squeezing line, above which there is no squeezing (Fig. 9). The average UCS of pyroxenite, chromitite and norite, which are the hangingwall, reef and footwall rock types respectively, are included in the graph. The graph indicates that chromitite $(\mathrm{CR})$, norite $(\mathrm{N})$ and pyroxenite (P) will experience squeezing conditions at depths of about 1400, 2950 and $3100 \mathrm{~m}$, respectively.

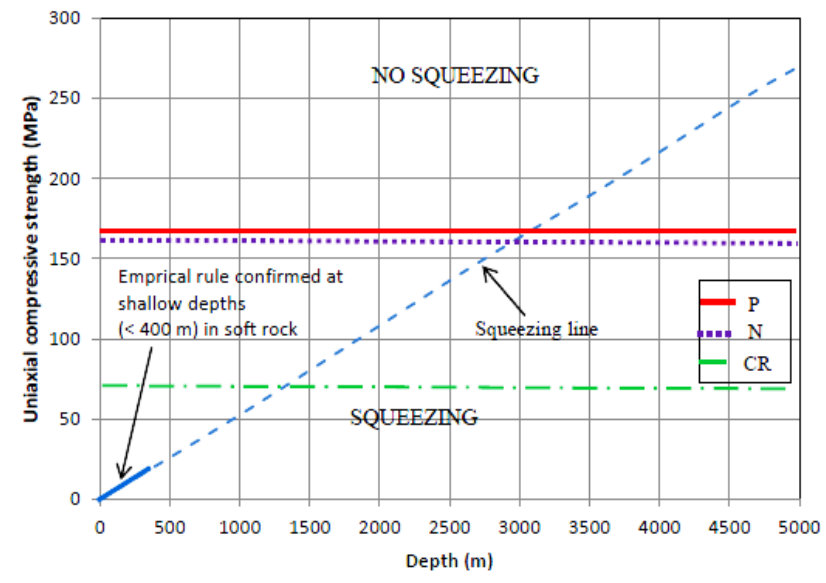

Figure 9. Hypothetical squeezing conditions of ultra-deep mining excavations in hard rocks (Malan \& Basson, 1998)

The horizontal and vertical displacement plots were used to monitor the relative displacement of hangingwall and sidewalls in the model. Vertical displacement (or convergence), $\Delta V$, is determined by considering the relative movement of the hangingwall and footwall, while the horizontal displacement, $\Delta H$, is determined by taking the relative movement of the sidewalls into account (Fig. 10). Table 8 summarises the horizontal and vertical displacement plots for all depths under consideration.

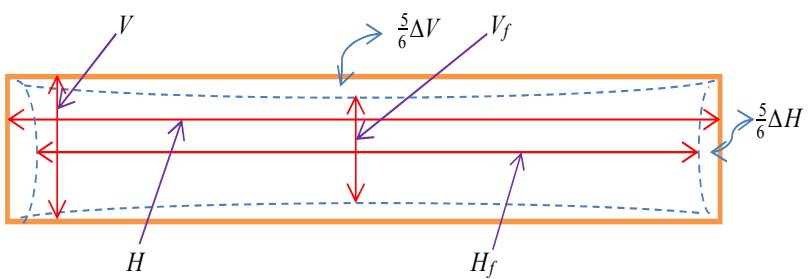

Figure 10. Illustration of horizontal and vertical displacements: $V$-vertical distance before stope is excavated; $H$-horizontal distance before stope is excavated; $V_{f}$-vertical distance after stope is excavated; $\boldsymbol{H}_{f}$ - horizontal distance after stope is excavated

Table 8. Summary of horizontal and vertical displacements

\begin{tabular}{ccc}
\hline Depth, $\mathrm{m}$ & $\begin{array}{c}\text { Horizontal } \\
\text { displacement, } \mathrm{mm}\end{array}$ & $\begin{array}{c}\text { Vertical } \\
\text { displacement, } \mathrm{mm}\end{array}$ \\
\hline 1073 & 2.0 & 1.5 \\
2835 & 13.6 & 19.6 \\
5038 & 35.8 & 62.9 \\
\hline
\end{tabular}

As observed in Table 8, both the horizontal and vertical displacements increase with increasing depth. In summary, the results show that mining at ultra-deep levels will pose a challenge of an increase in horizontal and vertical displacements. 


\subsection{Prediction of the depth of failure}

Equation (9) is the constant deviatoric stress equation proposed by Martin, Kaiser, \& McCreath (1999) for the depth of failure prediction in brittle rock mass:

$\frac{\sigma_{1}-\sigma_{3}}{\sigma_{c i}}=0.33$

where:

$\sigma_{1}, \sigma_{3}, \sigma_{c i}$ are the major principal stress, minor principal stress and the uniaxial compressive strength of the rock, respectively.

Equation (9) was written as a FISH function and included in the model for the evaluation of the extent and depth of failure in the hangingwall and sidewall. The points in the sidewall are labelled as $s_{1}, s_{2}$, and $s_{3}$ while that of hangingwall were represented as $h_{1}, h_{2}$, and $h_{3}$. The failures were examined at intervals of 1,2 and $3 \mathrm{~m}$ from the skin of the stope in both hangingwall and sidewall, as shown in Figure 11. Figure 12 presents the plot of the failure of the sidewall at $1073 \mathrm{~m}$ against time step while Figure 13 shows the comparison of the sidewall and hangingwall failure indicators at different depths.

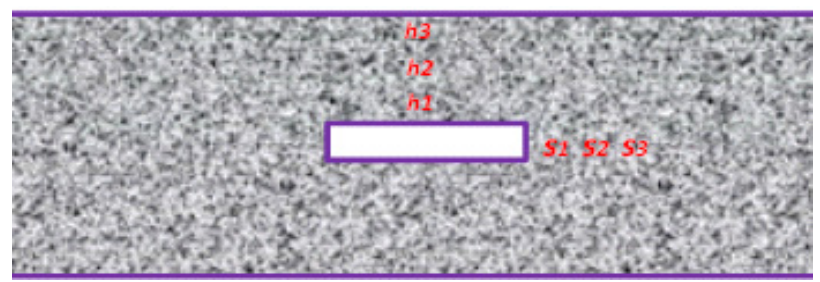

Figure 11. Illustration of failure measurement intervals

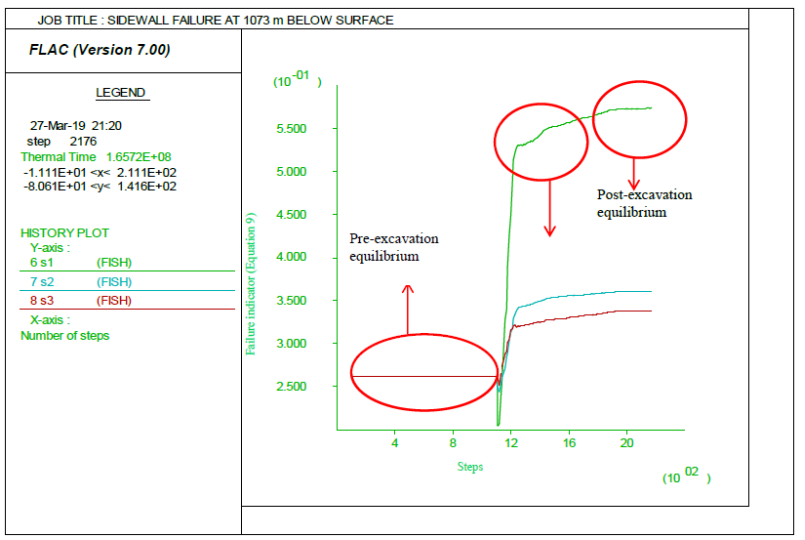

Figure 12. Sidewall failure indicator at $1073 \mathrm{~m}$ below the surface

\subsection{Sensitivity analysis}

Sensitivity analyses were done to evaluate the influence of temperature variation on failure in the model. This was achieved by assigning the temperature and thermal properties (coefficient of expansion, thermal conductivity and heat capacity) at a depth of $1073 \mathrm{~m}$ to that of $5038 \mathrm{~m}$ in order to observe the influence of lower temperature at high depth. The temperature and thermal properties for a depth of $5038 \mathrm{~m}$ were also assigned to that of $1073 \mathrm{~m}$ in order to observe the influence of higher temperature at shallow depth.

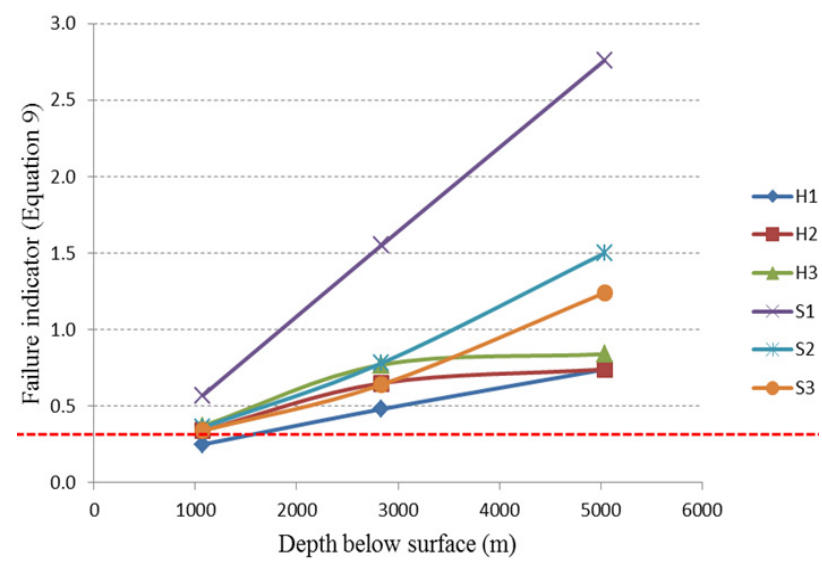

Figure 13. Comparison of the sidewall and hangingwall failure indicators at different depths

The modelling geometry and the remaining input parameters were kept constant. The temperature was increased from 50 to $140^{\circ} \mathrm{C}$ at $1073 \mathrm{~m}$ and reduced from 140 to $50^{\circ} \mathrm{C}$ at $5038 \mathrm{~m}$. The depths of 1073 and $5038 \mathrm{~m}$ were chosen for comparison since they are at the far ends on the depth scale.

Figures 14-16 show the state plots, while Table 9 presents the horizontal and vertical displacements for comparison.

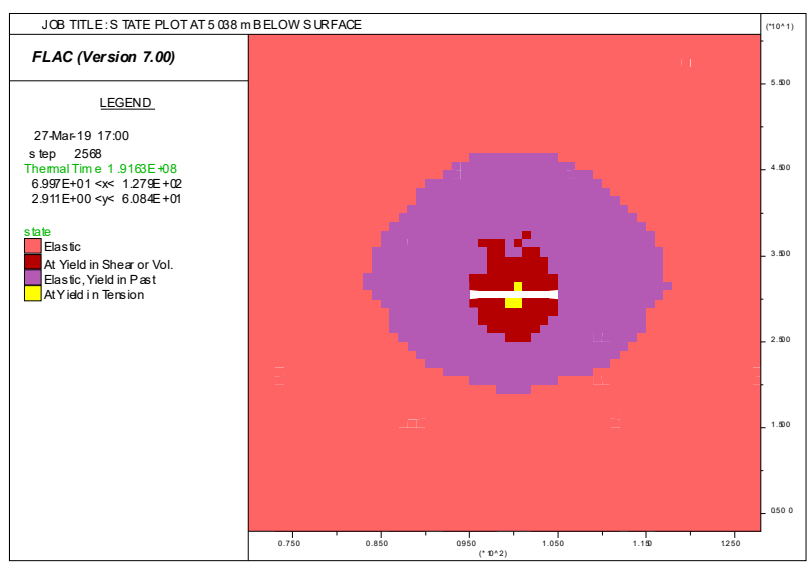

Figure 14. State plot for temperature $140^{\circ} \mathrm{C}$ at $5038 \mathrm{~m}$ below the surface

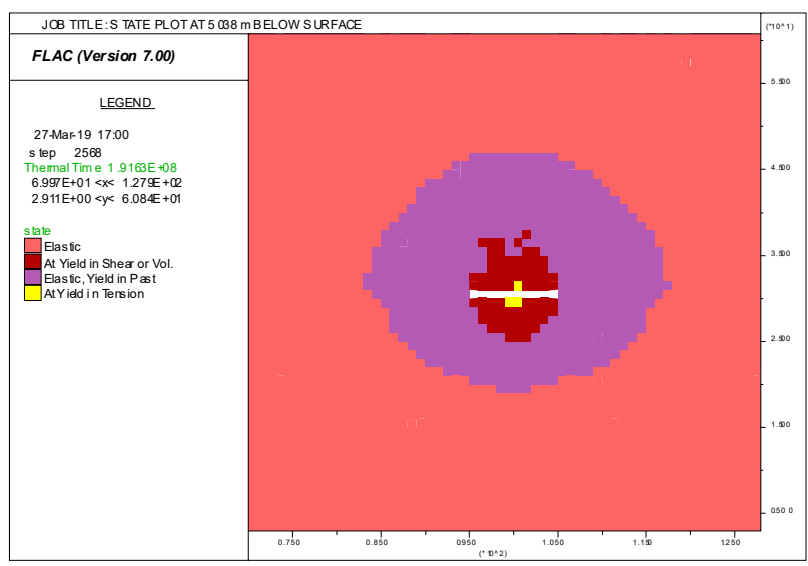

Figure 15. State plot for temperature $50^{\circ} \mathrm{C}$ at $5038 \mathrm{~m}$ below the surface 


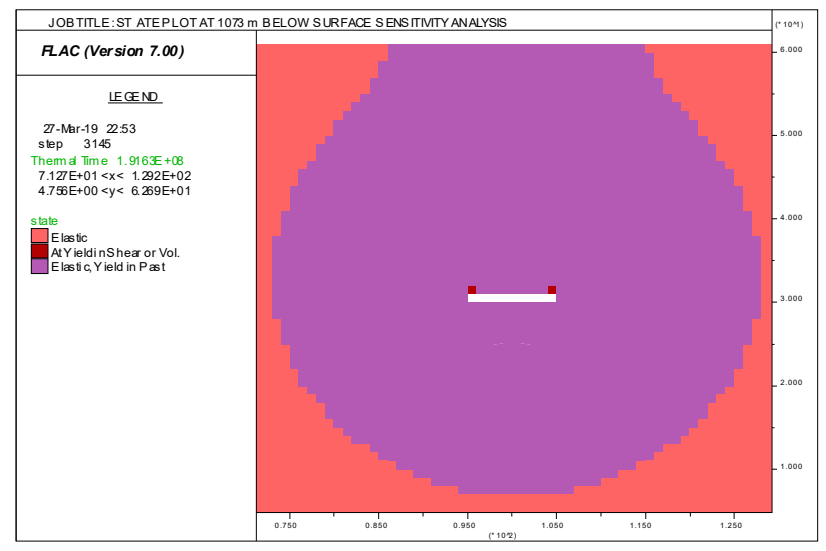

Figure 16. State plot for temperature $140^{\circ} \mathrm{C}$ at $1073 \mathrm{~m}$ below the surface

Table 9. The horizontal and vertical displacements from the sensitivity analyses

\begin{tabular}{|c|c|c|c|c|}
\hline \multirow[b]{2}{*}{ Depth, m } & $50^{\circ} \mathrm{C}$ & $140^{\circ} \mathrm{C}$ & $50^{\circ} \mathrm{C}$ & $140^{\circ} \mathrm{C}$ \\
\hline & \multicolumn{2}{|c|}{$\begin{array}{c}\text { Horizontal } \\
\text { convergence, } \mathrm{mm}\end{array}$} & \multicolumn{2}{|c|}{$\begin{array}{c}\text { Vertical } \\
\text { convergence, } \mathrm{mm}\end{array}$} \\
\hline 1073 & 2.0 & 2.5 & 1.5 & 2.3 \\
\hline 5038 & 43.0 & 36.0 & 90.4 & 63.0 \\
\hline
\end{tabular}

\subsection{Discussion}

Underground workings are constructed in stressed rock, and any excavation causes changes in the state of virgin stresses. To determine the stability in competent rocks, the knowledge of stress concentration around the opening is essential. Stresses around openings may reach the limit according to the failure criterion used that would result in further closure. Evaluation of stresses and displacements around such openings will then be a useful basis for engineering design and support (Malan \&Basson, 1998; Pérez Hidalgo \& Nordlund, 2012).

Nyungu \& Stacey (2014) observed that at shallow depth in the BIC, rock failure might be unexpected in underground openings because of the competence of rocks and relatively lower in-situ stress levels in comparison to the UCS of the rocks. Nyungu \& Stacey (2014), however, stated that fractures had been observed in the walls of excavations where the stress levels are well below the UCS. They further asserted that stress-induced failure could occur when the post-excavation stresses are as low as one quarter to one-half of the rock strength.

As can be seen from the state plots (Figs. 5-7) and the failure indicator plot (Fig. 13), increase in the in-situ stresses and temperature lead to a higher magnitude of failure except that there is a more tensile failure than shear failure at $5038 \mathrm{~m}$ below the surface. At $1073 \mathrm{~m}$ below surface, using Equation (5), the criterion proposed by Martin, Kaiser, \& McCreath (1999), only the hangingwall failure indicator value at $h_{1}$, is less than 0.33 , which implies that there would be no failure at position $h_{1}$ of the hangingwall. However, for the sidewall points at $s_{1}, s_{2}$ and $s_{3}$, the failure indicators from Equation (5) are greater than 0.33.

At the depth of $2835 \mathrm{~m}$, there is more failure as shown in the state plot (Fig. 6). As observed in Figure 13, hangingwall and sidewall failure indicators are higher at the depth of $2835 \mathrm{~m}$ than $1037 \mathrm{~m}$. The state plot shows that, in addition to shear failure, tensile failure could also be experienced at $2835 \mathrm{~m}$ below the surface. It is possible that the tensile failure is not only the result of increased in-situ stresses but also temperature. Volumetric expansion of the rocks takes place when the rock temperature increases. This expansion is a function of the thermal cracks induced by the heat energy (thermal stress). These thermal cracks were also observed in the microscopic analyses of the heated rocks that are cooled and viewed under the microscope (Oniyide \& Yilmaz, 2016). The generation of thermal cracks is also possible before the immediate walls of excavation are cooled through ventilation. The values of the failure indicators are well above 0.33 for both the hangingwall and the sidewall as shown in Figure 13 except for position $h_{1}$ of the hangingwall at $1073 \mathrm{~m}$. Therefore, all excavations across all levels would require more support that is conservative.

The observations from the previous two cases, at the depths of 1073 and $2835 \mathrm{~m}$ render the analysis at the depth of $5038 \mathrm{~m}$ to be more critical. Although, there is a reduction in the observed shear failure from the state plot (Fig. 7) as compared to that of $2835 \mathrm{~m}$, however, the extent of the horizontal, vertical displacement and tensile failures are higher due to the increase in temperature and in-situ stresses. Kaiser \& Kim (2008) affirmed that brittle, tensile rather than shear failure modes play a role at intermediate to high-stress levels and in massive to moderately jointed rock mass. Apart from the contribution of high in-situ stresses to tensile failure at $5038 \mathrm{~m}$, increased temperature also plays an essential role as shown in the sensitivity analyses (Table 9).

The horizontal and vertical convergences are 35.8 and $62.9 \mathrm{~mm}$, respectively at $5038 \mathrm{~m}$ below the surface. In comparison with the previous depths, stoping at $5038 \mathrm{~m}$ below the surface has the highest vertical convergence, which implies that roof sagging and floor heave will be more experienced than the relative deformation of the sidewalls. Based on the magnitude of convergence that will be experienced at ultra-deep mining levels (3500 to $5000 \mathrm{~m}$ ), it is recommended that access development is located in the more competent strata, such as in mottled anorthosite with an average UCS of $82 \mathrm{MPa}$. In addition, the use of yielding rock bolts, which allow significant deformation without failure, would be necessary.

Furthermore, longitudinal compression slots can be included in shotcrete to prevent a build-up of a load in the lining that would lead to failure. Malan \& Basson (1998) also suggested the use of flexible membrane support such as Everbond. Everbond is a versatile acrylic polymer emulsion that can be used either as a bonding adhesive or as an admixture that enhances Portland cement-based mixes, giving these mixes improved flexural, tensile and bond strength. They explained that a flexible membrane provides broken rocks with increased residual strength, even when subjected to large deformations.

Figure 15 shows a reduction in both the extent of shear and tensile failure in comparison with Figure 14 for the depth of $5038 \mathrm{~m}$ below the surface. In reality, this reduction is due to decreasing temperature. However, as observed in Table 9, the reduction of temperature increased the horizontal and vertical convergence from 36 and $63 \mathrm{~mm}$ to 43 and $90.4 \mathrm{~mm}$, respectively. In the case of $1073 \mathrm{~m}$ below the surface, increasing the temperature from 50 to $140^{\circ} \mathrm{C}$ increased the extent of shear and tensile failure and convergence as shown in Figures 15 and 16, and Table 9. 


\section{CONCLUSIONS}

This paper presents the numerical modelling of underground excavation, with particular reference to BIC in the South African Platinum mines. The study reveals that the combination of stress and higher temperatures influence the stability of under-ground openings. Tensile failure was observed to increase with increasing mining depth. The sensitivity analyses show that failure of rocks, especially in the BIC, with increasing depth is a function of both increasing in-situ stresses and higher temperatures.

It is recommended that horseshoe-shaped opening could be preferred in such conditions to avoid high-stress concentration at the corners of the roof of the stopes, which may reduce failures from shallow-depth to ultradepth levels. Also, based on the magnitude of convergence that will be experienced at ultra-deep mining levels $(3500$ to $5000 \mathrm{~m}$ ), it is recommended that access development is located in the more competent strata, such as in mottled anorthosite with an average UCS of $82 \mathrm{MPa}$. In addition, the use of yielding rock bolts, which allow significant deformation without failure, would be necessary. Furthermore, longitudinal compression slots can be included in shotcrete to prevent a build-up of a load in the lining that would lead to failure.

\section{ACKNOWLEDGEMENTS}

We appreciate the support of Mr. Andrew Carpede and Professor Halil Yilmaz of University of the Witwatersrand for their support.

\section{REFERENCES}

Barton, N., Lien, R., \& Lunde, J. (1974). Engineering classification of rock masses for the design of tunnel support. Rock Mechanics Felsmechanik Mecanique des Roches, 6(4), 189-236. https://doi.org/10.1007/bf01239496

Bieniawski, Z.T. (1976). Rock mass classification in rock engineering, 97-106.

Bieniawski, Z.T. (1989). Engineering rock mass classifications. New York, United States: Wiley.

Biffi, M., Stanton, D., Rose, H., \& Pienaar, D. (2007). Ventilation strategies to meet future needs of the South African platinum industry. The Journal of the South African Institute of Mining and Metallurgy, (107), 59-66.

Castro, L., Bewick, R., \& Carter, T. (2012). An overview of numerical modelling applied to deep mining. Innovative Numerical Modelling in Geomechanics, 393-414. https://doi.org/10.1201/b12130-22

Egerton, F.M.G. (2004). Presidential address: the mechanisation of UG2 mining in the Bushveld Complex. The Journal of The South African Institute of Mining and Metallurgy, 104(8), 439-455.

Handley, M.F. (2013). Pre-mining stress model for subsurface excavations in southern Africa. Journal of the Southern African Institute of Mining and Metallurgy, 113(6), 449-471.

Hoek, E., \& Brown, E.T. (1997). Practical estimates of rock mass strength. International Journal of Rock Mechanics and Mining Sciences, 34(8), 1165-1186. https://doi.org/10.1016/s1365-1609(97)80069-x
Hoek, E., Carranza-Torres, C., \& Corkum, B. (2002). HoekBrown criterion - 2002 edition. Proceedings NARMS-TAC Conference, 267-273.

Hoek, E., Kaiser, P.K., \& Bawden, W.F. (1995). Support of underground excavations in hard rock. Rotterdam, Netherlands: Balkema.

Itasca Consulting Group. (2012). FLAC (Fast Lagrangian Analysis of Continua) user's guide (Version 7.0). Minneapolis, Minnesota, United State: Itasca Consulting Group, Inc.

Jones, M. (2015). Thermophysical properties of rocks from the Bushveld Complex. Journal of the Southern African Institute of Mining and Metallurgy, 115(2), 153-160. https://doi.org/10.17159/2411-9717/2015/v115n2a10

Kaiser, P.K., \& Kim, B.-H. (2008). Rock mechanics challenges in underground construction and mining. Australian Centre for Geomechanics, (31), 1-5.

Kim, B., \& Yang, H. (2001). Behaviours of underground caverns in the storage of low temperature materials. In Frontiers of Rock Mechanics and Sustainable Development in the $21^{\text {st }}$ Century, 417-418.

Malan, D.F., \& Basson, F.R.P. (1998). Ultra-deep mining: the increased potential for squeezing conditions. The Journal of the Southern African Institute of Mining and Metallurgy, 353-364.

Malan, D.F., \& Napier, J.A.L. (2011). The design of stable pillars in the Bushveld Complex mines: a problem solved? The Journal of the Southern African Institute of Mining and Metallurgy, (111), 821-836.

Martin, C.D., Kaiser, P.K., \& McCreath, D.R. (1999). HoekBrown parameters for predicting the depth of brittle failure around tunnels. Canadian Geotechnical Journal, $36(1), 136-151$. https://doi.org/10.1139/t98-072

Nyungu, D., \& Stacey, T.R. (2014). Time-dependent tensile strengths of Bushveld Complex rocks and implications for rock failure around mining excavations. Proceedings $6^{\text {th }}$ Southern African Rock Engineering Symposium, 1-7.

Oniyide, G.O., \& Yilmaz, H. (2016). Microscopic analyses of Bushveld Complex rocks under the influence of high temperatures. Journal of the Southern African Institute of Mining and Metallurgy, 116(2). https://doi.org/10.17159/2411-9717/2016/v116n3a6

Pérez Hidalgo, K., \& Nordlund, E. (2012). Failure process analysis of spalling failure - comparison of laboratory test and numerical modelling data. Tunnelling and Underground Space Technology, (32), 66-77. https://doi.org/10.1016/j.tust.2012.05.005

Ryder, J.K., \& Jager, A.J. (2002). A handbook on rock engineering practice for tabular hard rock mines. Woodmead, South Africa: The Safety in Mines Research Advisory Committee.

Schouwstra, R.P., Kinloch, E.D., \& Lee, C.A. (2000). A short geological review of the Bushveld Complex. Platinum Metals Review, 44(1), 33-39.

Sellers, E.J. (2011). Controlled blasting for enhanced safety in the underground environment. The Journal of the Southern African Institute of Mining and Metallurgy, (111), 11-17.

Simpson, B. (2011). Reliability in geotechnical design - some fundamentals. Proceedings of the $3^{\text {rd }}$ International Symposium on Geotechnical Safety and Risk, 393-399.

Watson, B.P. (2010). Rock behaviour of the Bushveld Merensky Reef and the design of crush pillars. $\mathrm{PhD}$ Thesis. Johannesburg, South Africa: University of Witwatersrand, School of Mining Engineering. 


\section{ЧИСЕЛЬНЕ МОДЕЛЮВАННЯ ВПЛИВУ ТЕМПЕРАТУРНИХ ЗМІН НА СТАБІЛЬНІСТЬ ОЧИСНОГО ВИБОЮ У БУШВЕЛДСЬКОМУ МАГМАТИЧНОМУ КОМПЛЕКСІ}

\section{Г.О. Онійіде, М.А. Ідріс}

Мета. Вивчення впливу температури і напружень, що ростуть зі збільшенням глибини виробки, на стабільність очисного вибою у Бушвелдському магматичному комплексі (БМК), де знаходяться платинові рудники ПАР.

Методика. Для аналізу стабільності очисного вибою у платиновому руднику було застосовано чисельне моделювання. Для вивчення й розуміння поведінки породи при глибоких і високотемпературних підземних розробках використовувалася комерційна геотехнічна програма FLAC. Моделювання носило гіпотетичний характер у тому сенсі, що воно не грунтувалося на прямих польових вимірах обвалень або зсувів. Проте, деякі польові дані, отримані на рудниках, включали температуру первинної породи та внутрішньопластові напруження.

Результати. Дослідження показали, що розробка пласта на надглибоких рівнях супроводжується зростанням горизонтальних і вертикальних зсувів зі збільшенням глибини розробки. Криві пластично деформованих зон у моделі розробок на глибинах 1073, 2835 і 5038 м дозволили спрогнозувати обвалення при зсуві та від напружень на глибинах 2835 і 5038 м. Проте, на глибині 5038 м обвалення будуть більш значними порівняно 3 менш глибокими розробками, що може бути пояснено більш високими значеннями внутрішньопластових напружень і температури первинної породи.

Наукова новизна. Автори основних досліджень платинових рудників не розглядали в достатній мірі вплив зростання температури у виробках на надглибоких рівнях, тому дана робота заповнює прогалину у вивченні впливу збільшення температури та напружень на стабільність очисних вибоїв на надглибоких рівнях у БМК.

Практична значимість. Рекомендовано застосовувати вибій підковоподібної форми для запобігання формування концентрації високих напружень у кутах покрівлі вибою. Рекомендовано в умовах надвисоких глибин (від 3500 до 5000 м) розташовувати виробку в більш стійких пластах, таких як крапчастий анортозит із середньою межею міцності на одновісний стиск 82 МПа.

Ключові слова: зміна температури, чисельне моделювання, лабораторні випробування, Бушвелдські породи, платинові рудники

\section{ЧИСЛЕННОЕ МОДЕЛИРОВАНИЕ ВЛИЯНИЯ ТЕМПЕРАТУРНЫХ ИЗМЕНЕНИЙ НА СТАБИЛЬНОСТЬ ОЧИСТНОГО ЗАБОЯ В БУШВЕЛДСКОМ МАГМАТИЧЕСКОМ КОМПЛЕКСЕ}

\section{Г.О. Онийиде, М.А. Идрис}

Цель. Изучение влияния температуры и напряжения, растущих с увеличением глубины выработки, на стабильность очистного забоя в Бушвелдском магматическом комплексе (БМК), где находятся платиновые рудники ЮАР.

Методика. Для анализа стабильности очистного забоя в платиновом руднике было применено численное моделирование. Для изучения и понимания поведения породы при глубоких и высокотемпературных подземных разработках использовалась коммерческая геотехническая программа FLAC. Моделирование носило гипотетический характер в том смысле, что оно не основывалось на прямых полевых измерениях обрушений или сдвигов. Однако, некоторые полевые данные, полученные на рудниках, включали температуру первичной породы и внутрипластовые напряжения.

Результаты. Исследования показали, что разработка пласта на сверхглубоких уровнях сопровождается ростом горизонтальных и вертикальных сдвигов с увеличением глубины разработки. Кривые пластически деформируемых зон в модели разработок на глубинах 1073, 2835 и 5038 м позволили спрогнозировать обрушения при сдвиге и от напряжения на глубинах 2835 и 5038 м. Однако, на глубине 5038 м обрушения будут более значительными по сравнению с менее глубокими разработками, что может быть объяснено более высокими значениями внутрипластовых напряжений и температуры первичной породы.

Научная новизна. Авторы основных исследований платиновых рудников не рассматривали в достаточной степени влияние роста температуры в выработках на сверхглубоких уровнях, поэтому данная работа восполняет пробел в изучении влияния увеличения температуры и напряжений на стабильность очистных забоев на сверхглубоких уровнях в БМК.

Практическая значимость. Рекомендовано применять забой подковообразной формы для предотвращения формирования концентрации высоких напряжений в углах кровли забоя. Рекомендовано в условиях сверхвысоких глубин (от 3500 до 5000 м) располагать выработку в более устойчивых пластах, таких как крапчатый анортозит со средним пределом прочности на одноосное сжатие 82 МПа.

Ключевые слова: изменение температуры, численное моделирование, лабораторные испытания, Буивелдские породы, платиновые рудники 


\section{ARTICLE INFO}

Received: 3 March 2019

Accepted: 4 June 2019

Available online: 7 June 2019

\section{ABOUT AUTHORS}

Gafar Omotayo Oniyide, Doctor of Philosophy, the School of Mining Engineering, University of the Witwatersrand, 1 Jan Smuts Ave., 2000, Johannesburg, South Africa; Lecturer of the Department of Mining Engineering, Federal University of Technology Akure, Ilesha-Akure Expressway, P.M.B. 704, Akure, Ondo State, Nigeria. E-mail: engroniyide@gmail.com

Musa Adebayo Idris, Doctor of Philosophy, Postdoctoral Research Fellow of the Division of Mining and Rock Engineering, Luleå University of Technology, SE-97187, Luleå, Sweden; Senior Lecturer of the Department of Mining Engineering, Federal University of Technology Akure, Ilesha-Akure Expressway, P.M.B. 704, Akure, Ondo State, Nigeria. E-mail: maidris@,futa.edu.ng 